\title{
EXPERIMENTAL RESEARCH IDENTIFIES MAIN PARAMETERS OF THE VENTURY EJECTOR INFLUENCE TO THE SYNGAS WASHING AND COOLING QUALITY IN THE SMALL-SCALE RICE HUSK GASIFIER
}

\author{
BUI TRUNG THANH, NGUYEN HOANG KHOI \\ Faculty of Heat and refrigeration engineering, Industrial University of Ho Chi Minh city; \\ buitrungthanh@hui.edu.vn
}

\begin{abstract}
Using the syngas of residues agriculture gasification process as gas fuel for supplying the dual - fuel engine to generate electricity in the rice mills is not popular in Viet Nam. This research content belongs to the national key program, which was conducted by the researchers of the Industrial University of Industry. The paper presented the experimental study to determine the key parameters of syngas filter and clarification combined cooling for Ejector venture equipment which was assembled rice husk gasification line for supplying the syngas fuel to the dual -fuel engine combined generator $5.5 \mathrm{~kW}$. The results are determination the nozzle level into ejector venture is $\mathrm{H}=30 \mathrm{~mm}$, the spray water pressure into is $\mathrm{P}=2 \mathrm{kgf} / \mathrm{cm}^{2}$ and the spray water flow is $\mathrm{Q}=1.2$ liter/minute. These key factors are suitable for producing the syngas quality into the dual-fuel engine. These results were used in calculating, designing, manufacturing the rice husk gasifier line for supplying electricity and heating power for the rice mills with capacity $6-10$ tons paddy/hour at the Mekong delta river.
\end{abstract}

Keywords. wet syngas filter, syngas, rice husk gasification, syngas composition, water sprayer, pressure of water sprayer, flow of sprayer, syngas temperature, impurities rate of syngas.

\section{INTRODUCTION}

Rice husk is the agricultural waste which can be used for producing syngas by gasification process that was applied in India, Thailand.Vietnam is also the country has developing agricultural manufacturing, therefore, the rice husk is a potential country. Every year, the Mekong river Delta produces over 6 milliontons of rice husk [1]. Gasification is the conversion of biomass to a gaseous fuel by heating in a gasification medium such as air, oxygen or steam. The gasification technology was applied from 17 century, it was considered as one of the available methods of replaceable fuel for fossil fuel and reduction in environmental impact as well as offering an interesting solution to waste disposal. The products from gasification process were cleaned and cooled then were converted into heat and generation by using traditional approaches like the internal engine or gas turbine. We can call the products from gasification process is producer gas. The gases product from the gasification process is high temperature $\left(700-750^{\circ} \mathrm{C}\right)[9]$, the producer gas temperature into the washing and cooling equipment is around $300^{\circ} \mathrm{C}$ [2], they also comprise combustible and incombustible gases $\mathrm{CO}, \mathrm{H}_{2}, \mathrm{CH}_{4}$ and $\mathrm{CO}_{2}, \mathrm{~N}_{2}$, $\mathrm{O}_{2} \ldots$, respectively. The syngas from gasification process which uses the internal engine as fuel must be cooled down $40^{\circ} \mathrm{C}-30^{\circ} \mathrm{C}$ [8] and must be removed the contaminant contents before getting it for engine operation.

Gas cleaning is required for the separation of particles, tar components and impurities from raw producer gas leaving the gasifier. For producer gas cleaning can be used some different methods, such as cyclone, electrostatic precipitator, bag filter. The combination of cooling and cleaning can be used wet scrubbers. The wet scrubbers which can be used Spray tower, Cyclone spray tower, Sieve plate scrubbers, Venture scrubbers and packed bed scrubbers [6].

The ejector is one of venture scrubbers which have been successfully for polluted gas cleaning application [7]. The research contents for KC05/11-15 subject was conducted on rice husk material which used gasification technology for supplying thermal and electrical power to rice mill with capacity $6-10$ tons/hour. The ejector venture also was conducted on research and calculating for manufacturing, it was used in the assembly line in rice husk gasifier. The rice husk gasifier assembly line located on The Milling and Processing Food Factory No 1, it belongs to The Tien Giang Food Company. The paper 
presented the experimental results of cleaning and cooling the syngas product in the ejector venture scrubber for determination of water flow Q (liter/second), spray water pressure $\mathrm{P}\left(\mathrm{kgf} / \mathrm{cm}^{2}\right)$ and the nozzle assembly level $\mathrm{H}(\mathrm{mm})$ to the syngas flow.

\section{MATERIAL AND METHOD}

\subsection{Selection the target and input parameters influence on the ejector venture}

The functions of ejector venture are cleaning and cooling the syngas product, these functions were defined in the paper [3]. The quality of syngas product was determined by three target parameters.

\subsubsection{The target parameters}

The outlet syngas temperature: This parameter is used for evaluating of cooling efficiency. The experiment showed that the syngas temperature is over $300^{\circ} \mathrm{C}$ but the suitable temperature into internal engine require lower $40^{\circ} \mathrm{C}[8]$. In this research, the syngas temperature is used as symbol $\left(\mathrm{Y}_{1}\right)$

The solid particle concentration of syngas: It influences on the syngas quality into the internal engine. This parameter is referred to syngas standard into the internal engine [8] and is used as symbol $\left(\mathrm{Y}_{2}\right)$

The syngas composition: The cleaning and cooling of syngas to improve its quality for supplying the internal engine, however; this process does not reduce the heating value of syngas product. In an experiment, this factor is not mentioned.

\subsubsection{The input parameters}

There are many factors influence on the syngas quality in the ejector venture, such as the nozzle type, the spray water pressure, the water flow, the nozzle level in washing and cooling. Based on theory and analyze, the author selected three factors influence on the syngas quality after ejector venture:

\section{Spray water pressure}

The density and droplet size of spray water influence on the cleaning and cooling of syngas product. They depend on spray pressure into the nozzle. The droplet size has a relation with spray pressure directly. The more spray pressure increase, the more droplet diameter become small and on contrary. There for, it is necessary to conduct experiments to determine the suitable droplet size and spray pressure into the ejector venture, however, the specific value should be determined due to influence on the pump power as the spray pressure increase. The symbol of spray water pressure is used $\left(\mathrm{X}_{1}\right)$

\section{The water flow into the nozzle}

The water flow into the nozzle influence on cleaning dust particles and cooling syngas. The experiments to find the suitable rate of water flow and syngas flow. In fact, the more water flow was supplied, the more syngas was cooled and cleaned, however; it influences on wastewater flow and treated wastewater capacity system. The symbol of water flow is used $\left(\mathrm{X}_{2}\right)$

\section{The nozzle level into syngas flow}

The height $\mathrm{H}$ of the nozzle is level from spray water point to syngas flow center. The height influence on the droplet density and spray angle into syngas flow. As the height changed, the spray angle will be changed, it can be expanded or narrowed. The experiments determine the suitable height in controlling the contact rate between spray water and syngas efficiently. The symbol for the height of nozzle is used $\left(\mathrm{X}_{3}\right)$

\subsection{Model description}

- Reactor (1) was designed which based on a positive principle, the air and fuel are charged at the top of the gasifier and certainly, the air will come out at the bottom of the gasifier. The mechanical parts are assembled in the bottom in order to remove ash. The husk and the air flow consumption are $14.5 \mathrm{~kg} / \mathrm{h}$ and $55 \mathrm{~m}^{3} / \mathrm{h}$, respectively.

- Cyclone (2): It was designed and located after the gasifier in order to collect almost the dust which following the syngas.

- Washing and cooling equipment (3): It was calculated and designed as a description in [1]. 
- The exhaust fan (4): It was designed to supply adequate the agent gasification flow and can be adjusted according to the requirements of the gasification mode. The exhaust fan is the high-pressure type with power $2 \mathrm{hp}$.

- The high - pressure water pump with pressure rate $30 \mathrm{kgf} / \mathrm{cm}^{2}$ was used for supplying spray water into the washing and cooling device.

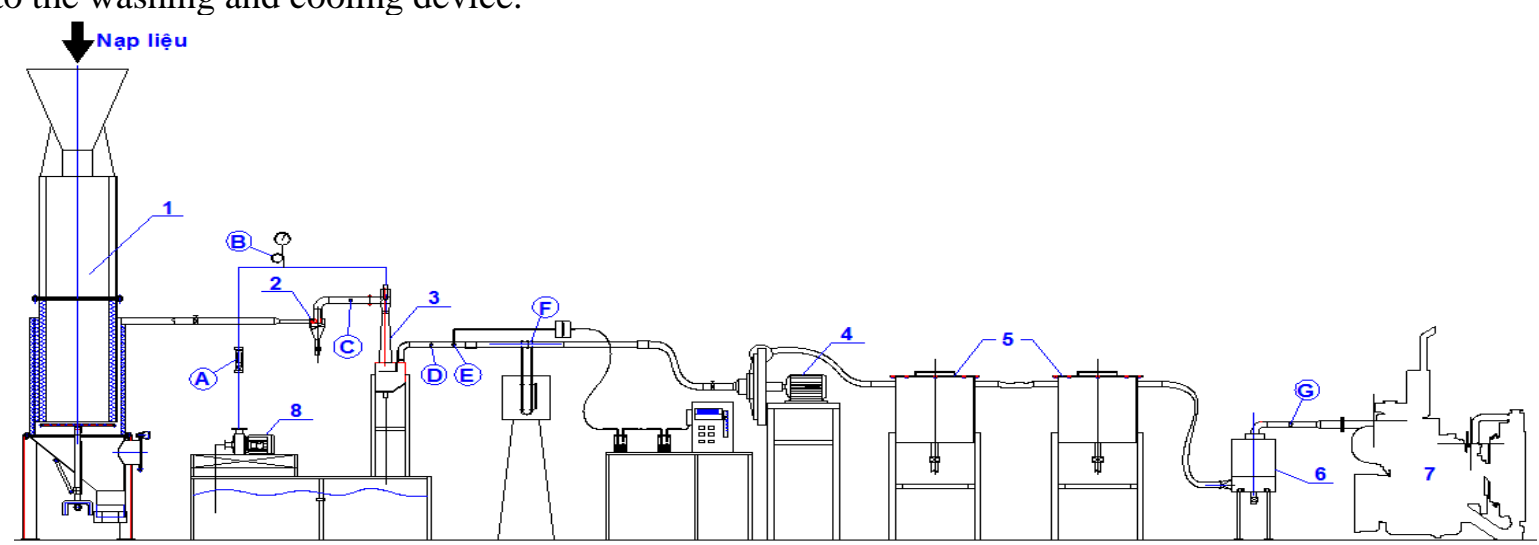

1 - Gasifier; 2 - Dust collector (Cyclone); 3 - Washing and cooling equipment; 4 - The exhaust fan; 5 Fine filter combination; 6 - Dry filter; 7 - Diesel engine RV125-2N; 8 - Pump is used for supplying the water to wash and cool the syngas; A, B, C, D, E, F, G: Measuring points.

Figure 1. Experimental model of rice husk gasification.

\subsection{Instruments for measurement}

To determine the input variables and the objective functions we used the instruments for measurement such as: a electronic thermometer of FT 1300-2, its temperature ranges is from $50{ }^{\circ} \mathrm{C} \sim 130^{\circ}$ with its basic accuracy is $\pm 1^{\circ} \mathrm{C}$. a Orifice instruments measures the water flow of pump. a gas samplier of 224-PCXR8 has an operating range from 5 to $500 \mathrm{ml} / \mathrm{min}$; a water pressure gauges with its maximum measuring is $15 \mathrm{~kg} / \mathrm{cm}^{2}$ with its range is $0,5 \mathrm{~kg} / \mathrm{cm}^{2}$. a vernier caliper used to measure the position height of sprayer.

\subsection{Experimental procedure}

The figure 1 and figure 2 show the measurement point positions in experiments. A: spray water flow into the nozzle; $\mathrm{B}$ : spray water pressure; $\mathrm{C}$ : inlet temperature into the ejector venture $\mathrm{T}_{1} ; \mathrm{D}$ : outlet temperature $\mathrm{T}_{2}$; E: the getting dust particles sample; F: the syngas flow outlet the ejector venture; $\mathrm{G}$ : the syngas composition and heating value.

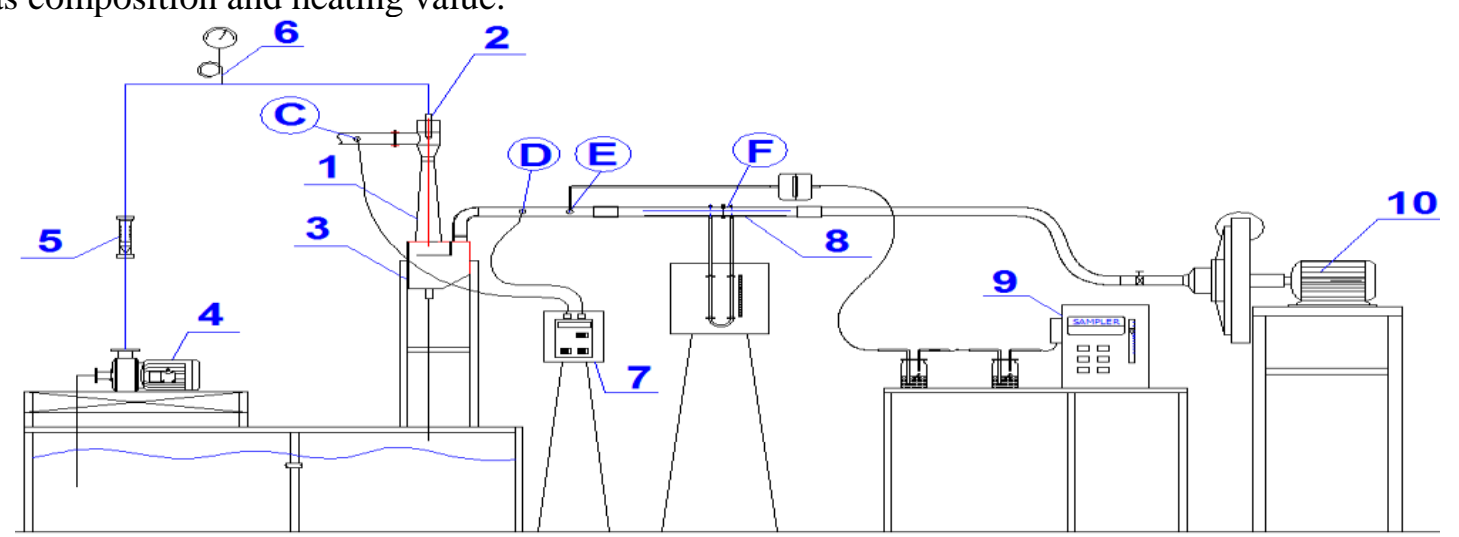

1 - The washing and cooling equipment; 2 - Spray nozzle; 3 - Separation box; 4 - Supplying pump; 5 measurement flow; 6 - Pressure measurement; 7 - Temperature measurement; 8 - Flow measurement; 9

- Pump for getting the dust particles sample; 10 - Exhaust fan.

Figure 2. The diagram measurement points before and after the washing and cooling equipment 


\subsubsection{Determination of the height of nozzle to the outlet syngas temperature and the solid particle concentration of syngas.}

The set up to determine the influence of the height of nozzle into syngas flow on outlet syngas temperature $Y_{1}\left({ }^{0} \mathrm{C}\right)$ and the solid particle concentration of syngas $Y_{2}\left(\mathrm{mg} / \mathrm{Nm}^{3}\right)$, then determination of the suitable height for the base level in other research steps. The levels in experiments including $20 \mathrm{~mm}, 25$ $\mathrm{mm}, 30 \mathrm{~mm}, 35 \mathrm{~mm}, 40 \mathrm{~mm}$. The fixed parameters are that the spray water pressure $2 \mathrm{kgf} / \mathrm{cm}^{2}$, the water flow into the nozzle 1.2 liter/minute, the agent velocity into gasifier $6 \mathrm{~cm} / \mathrm{second}$, ambient temperature $32^{\circ} \mathrm{C} \div 34^{0} \mathrm{C}$; air moisture: $60 \% \div 68 \%$.

\subsubsection{Determination of the spray water pressure to the outlet syngas temperature and the solid particle concentration of syngas}

The setup to determine the influence of the spray water pressure to syngas flow in washing and cooling equipment on syngas temperature $\mathrm{Y}_{1-2}\left({ }^{\circ} \mathrm{C}\right)$, the solid particle concentration of syngas $\mathrm{Y}_{2-}$ $2\left(\mathrm{mg} / \mathrm{Nm}^{3}\right)$, then determinate of the suitable spray water pressure for other research steps. The levels (P) in experiments including: $1 \mathrm{kgf} / \mathrm{cm}^{2} ; 1.5 \mathrm{kgf} / \mathrm{cm}^{2} ; 2 \mathrm{kgf} / \mathrm{cm}^{2} ; 2.5 \mathrm{kgf} / \mathrm{cm}^{2}$ và $3 \mathrm{kgf} / \mathrm{cm}^{2}$. The fixed parameters are that the height of the nozzle assembly is $30 \mathrm{~mm}$; water flow into the nozzle is 1.2 liter/minute; the agent velocity into gasifier is $6 \mathrm{~cm} /$ second; ambient temperature $32^{\circ} \mathrm{C} \div 34^{0} \mathrm{C}$; air moisture $60 \% \div 68 \%$.

\subsubsection{Determination of spray water flow to the outlet syngas temperature and the solid particle concentration of syngas}

The set up to determine the influence of the spray water flow on the targets output, those are the outlet syngas temperature $\left({ }^{0} \mathrm{C}\right)$ and the solid particle concentration of syngas $\left(\mathrm{mg} / \mathrm{Nm}^{3}\right)$, then determine the suitable spray water flow for other research steps. The levels $(\mathrm{Q})$ in experiments including 0.8 liter/minute; 1 liter/minute; 1.2 liter/minute; 1.4 liter/minute; 1.6 liter/minute. Experimental conditions are that the height of the nozzle assembly is $30 \mathrm{~mm}$; spray water pressure into the nozzle is $2 \mathrm{kgf} / \mathrm{cm}^{2}$; the agent velocity into gasifier is $6 \mathrm{~cm} / \mathrm{second}$; ambient temperature $32^{\circ} \mathrm{C} \div 34^{\circ} \mathrm{C}$; air moisture: $60 \% \div 68 \%$.

\subsection{Record data and results}

Duration for recording data in each experiment is 30 minutes, the random moment for starting. Experiments carry out 5 times over, then getting an average value. The process for the data record and getting the sample for analyzing were conducted randomly [4]. The data record was analyzed by SPSS software [5].

\section{RESULTS AND DISCUSSION}

\subsection{Influence of the nozzle height $(\mathrm{H})$ on the outlet syngas temperature}

The experimental results are shown in Fig 3. The value of assembly the nozzle is limited from $20-40$ $\mathrm{mm}$. In level $40-10 \mathrm{~mm}$, the syngas temperature decrease and get a minimum value as the nozzle at the center of syngas flow. This can be explained due to spray water contact to syngas flow efficiently. The syngas temperature increases gradually when the nozzle height reduce. The regression equation of the influence of the nozzle height $(\mathrm{H})$ on outlet syngas temperature was built in equation (1).

$$
\mathrm{t}=0.093 * \mathrm{H}^{2}-5.925 * \mathrm{H}+166.148
$$




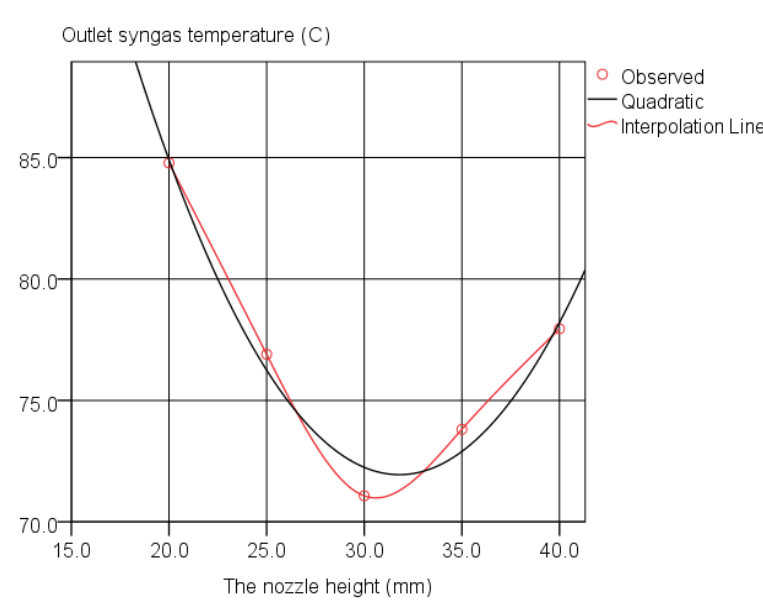

Figure 3. The relation between the height of nozzle and the outlet syngas temperature with its correlation coefficient are 0,98 and square $\mathrm{R}$ is 0,99

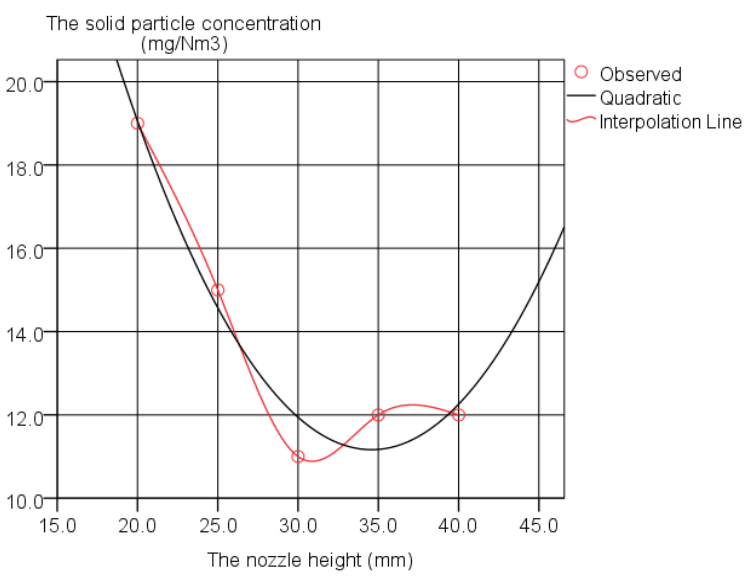

Figure 4. The relation between the height of nozzle and the solid particle concentration with its correlation coefficient are 0,97 and square $\mathrm{R}$ is 0,98

\subsection{Influence of the nozzle height $(\mathrm{H})$ on the solid particle concentration of syngas}

This experiment determined the influence of the nozzle level $(\mathrm{H})$ to the solid particle concentration of syngas after the washing and cooling equipment. The experimental results are shown in Fig 4. The observation during experiment showed that the height of nozzle in the top side is efficient for washing and cooling syngas. The nozzle was located in top side position was better than in bottom side and was suitable at $\mathrm{H}=30 \mathrm{~mm}$. The statistical analysis was conducted and built regression equation between the height of the nozzle and the solid particle concentration in equation (2). (The symbol $\mathrm{C}$ is used for the solid particle concentration of syngas, $\mathrm{mg} / \mathrm{Nm}^{3}$ ).

$$
\mathrm{C}=0.037 * \mathrm{H}^{2}-2.569 * \mathrm{H}+55.571
$$

\subsection{Influence of the spray water pressure $(P)$ on the outlet syngas temperature}

The experimental results are shown in Fig 5. The observation during experiment showed that the relation between spray water pressure and outlet syngas temperature towards linear. Influence of spray water pressure is not higher than water flow to the outlet syngas temperature. The regression equation was built as equation (3).

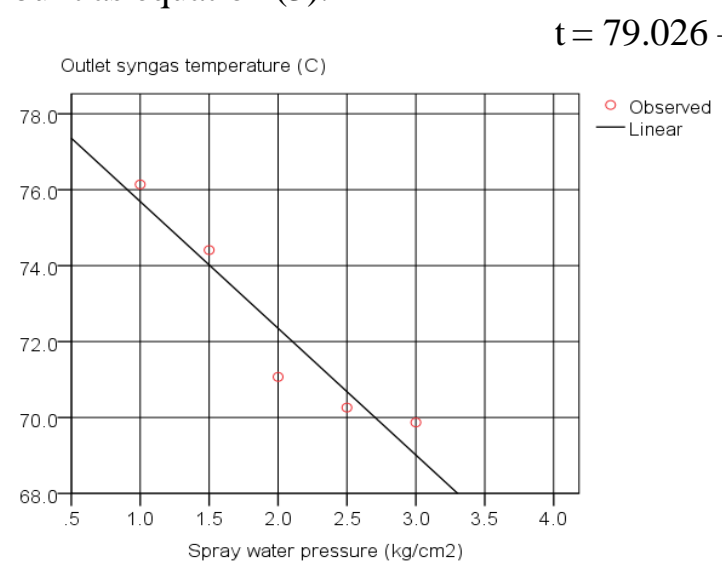

Figure 5. The relation between spray water pressure and the outlet syngas temperature with its correlation coefficient are 0,99 and square $\mathrm{R}$ is 0,99

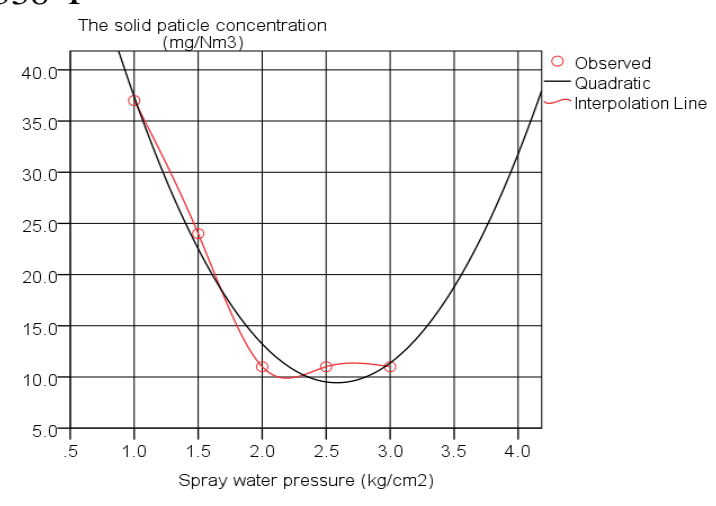

Figure 6 . The relation between spray water pressure and the solid particle concentration with its correlation coefficient are 0,98 and square $\mathrm{R}$ is 0,98 


\subsection{Influence of spray water pressure on the solid particle concentration of syngas}

The statistical analysis was conducted at experimental levels, then regression equations of relation spray water pressure with the solid particle concentration of syngas $\left(\mathrm{Y}_{2-2}\right)$ was built as equation (4).

$$
\mathrm{C}=11.143 * \mathrm{P}^{2}-57.571 * \mathrm{P}+83.800 \text { (4) }
$$

The spray water pressure has influence on cleaning efficiency in the washing and cooling equipment, the experiment results showed in Fig 6. The spray water pressure increases from $1 \mathrm{kgf} / \mathrm{cm}^{2}$ to $2 \mathrm{kgf} / \mathrm{cm}^{2}$, the dust particles rate changes significantly, then the pressure increases are not meaning in handling large dust particles size, the fine dust particle will be removed at high pressure.

\subsection{Influence of spray water flow to the outlet syngas temperature and the solid particle concentration of syngas}

The statistical analysis of the results was conducted at experimental levels, then regression equations of relation spray water flow with the outlet syngas temperature and the statistical analysis of relation spray water flow with the rest dust particles were built in equation (5) and (6), respectively.

The experiment results were shown as Fig 7 and Fig 8. The relation of the spray water flow influence on the outlet syngas temperature towards linear. The syngas temperature is very low at $1.4 \mathrm{liter} / \mathrm{minute}$ and 1.6 liter/minute, however, the moisture will be entrained airflow very much at the same time. The relation of the spray water flow influence on the solid particle concentration of syngas also towards linear, the more spray water flow increase, the more solid particle concentration reduce, however, at the maximum level 1.6 liter/minute is not suitable for this small experimental pilot cause of the large of moisture was entrained airflow.

$$
\begin{aligned}
& \mathrm{t}_{3}=125.806-43^{*} \mathrm{Q}_{3} \\
& \mathrm{C}=21.20-8.5 * \mathrm{Q}_{3}
\end{aligned}
$$

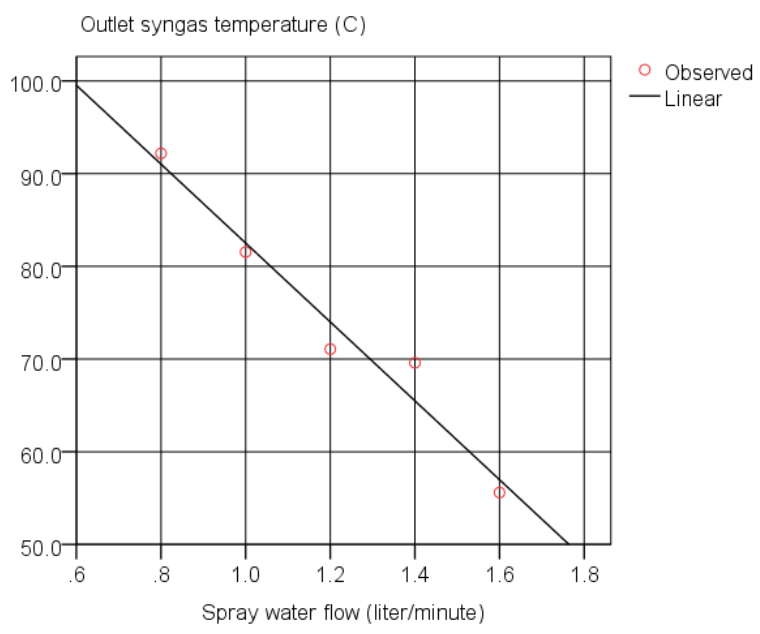

Figure 7. The relation between spray water flow and the outlet syngas temperature with its correlation coefficient are 0,99 and square $\mathrm{R}$ is 0,99

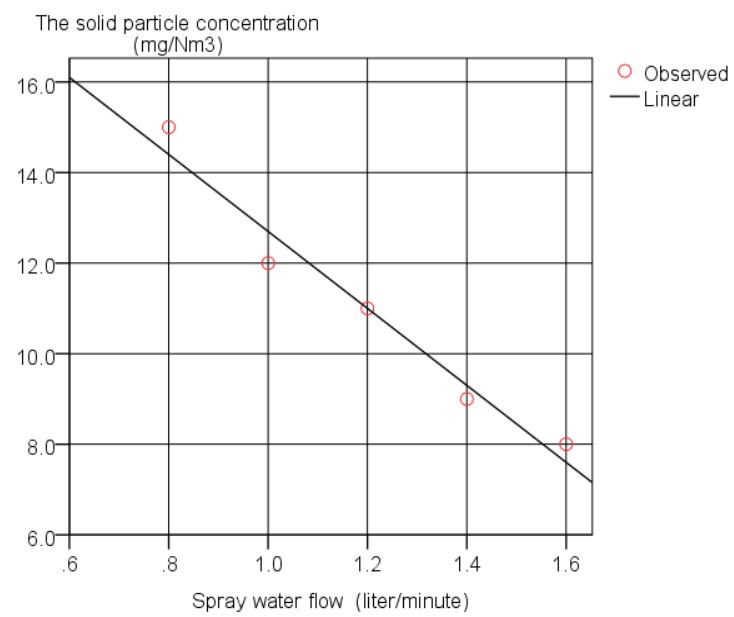

Figure 8 . The relation between spray water flow and the solid particle concentration with its correlation coefficient are 0,98 and square $\mathrm{R}$ is 0,99

\section{CONCLUSION}

The experiments determined three input factors which have the influence on the outlet syngas temperature and the solid particle concentration of syngas after the ejector venture equipment, these results were considered in order to design a washing and cooling like ejector venture in industrial scale efficiently. The experiments showed for each detail cases as below:

Height nozzles $(\mathrm{H})$ was arranged within the limits of $20-40 \mathrm{~mm}$. The outlet syngas temperature decreases with the increase of $\mathrm{H}$ and reached the lowest value when the nozzle position at the center of 
syngas flow in the pipeline, in which the solid particle concentration of syngas reached the best value as well in this position. When to decrease or increase the $\mathrm{H}$ from the center, the solid particle concentration of the syngas increases.

The relation of spray water pressure nozzle and outlet syngas temperature is linear, but it varies with the concentration of solid particle is quadratic function and the best efficiently for solid particles cleaning at $2 \mathrm{kgf} / \mathrm{cm}^{2}$ level of spray water pressure. The relation between water flow inlet with washing and cooling efficiency were observed at 1.2 liters/minute and they have a linear relation.

The experiments were conducted and determined the suitable operation for ejector venture reached washing and cooling efficiently which adapted to supply dual-fuel engine diesel, the results have shown that the height of nozzle is $30 \mathrm{~mm}$, spray water pressure is $2 \mathrm{kgf} / \mathrm{cm}^{2}$, inlet water flow is $1.2 \mathrm{liters} / \mathrm{minute}$.

\section{ACKNOWLEDGE}

The authors would like to sincerely thank the Ministry of Science and Technology for providing funding for the implementation of the subject code KC05.02/11-15 "Researching, calculating, designing, manufacturing for the assembly line which used rice husk for supplying energy to rice mills with capacity $6-10$ tons/hour".

\section{REFERENCES}

1. Bui Trung Thanh(2015),Researching, calculating, designing, manufacturing for the assembly line which used rice husk for supplying energy to rice mills with capacity 6 - 10 tons/hour", The science report of R\&D subject of KC05.02/2011-2015.

2. Bui Trung Thanh (2012),The experimental study identified some key parameters which affect the operation of the small-scale down draft rice husk gasifier, Journal of Science and Technology of Danang University

3. Bui Trung Thanh, Nguyen Hoang Khoi, Nguyen Van Tuyen(2014),Research, designing the syngas washing and cooling equipment of the rice husk gasification assembly line to supply gas fuel to the dual fuel diesel power generator $180 \mathrm{kVA}$, Journal of Viet Nam Mechanical engineering

4. Pham Van Lang, Bach Quoc Khang(1999), Theory foundation and application of Experimental planning in agriculture, Agriculture Publishing House, Hanoi,

5 Vo Van Huy, Vo Thi Lan, Hoang Trong(1997),Application of SPSS for windows to process and analyzing data research in marketing, administration, economic, psychology, society, Science and Technology Publishing house.

7. Agrawal. K.S(2013) Performance of Venturi Scrubber, International Journal of Engineering Research and Development, vol. 7, pp. 53-69, Jul. 2013.

6. Calvert.S, J.Goldschmid, D.Leith, and D.Mehta(1972),Wet Scrubber System Study, vol.1, Scrubber Handbook, US. Environmental Protection Agency, Aug. 1972.

8. L.C. Laurence and D. Ashenafi(2012), Syngas Treatment Unit for Small Scale Gasification - Application to IC Engine Gas Quality Requirement, Ecole des Mines de Nantes, GEPEA UMR CNRS 61444 rue A. Kastler, BP 20277, 44307 Nantes Cedex 3, France,Vol. 5, No.1, pp. 95-103, 2012.

9. T.B. Reed-A Dad, Handbook biomass downdraft gasifier engine system, Golden Colorado, March 1988. 


\section{NGHIÊN CỬU THỰC NGHIÊMM XÁC ĐỊNH MỘT SỐ THÔNG SỐ CHÍNH ẢNH HƯởNG ĐẾN CHẤT LƯợNG RỬA VÀ LÀM MÁT CỦA THIẾT BỊ EJECTOR VENTURY ĐỐI VỚI SẢN PHẨM KHÍ HÓA TRÊN MÔ HÌNH KHÍ HÓA QUY MÔ NHỎ}

Tóm tắt. Sử dụng sản phẩm khí hóa làm nhiên liệu cho động cơ diesel sử dụng nhiên liệu kép để vận hành tổ máy phát điện cung cấp điện cho các nhà máy xay xát là vấn mới ở Việt Nam. Trong chương trình hướng đến tiết kiệm và sử dụng hiệu quả năng lượng, nội dung nghiên cứu này được chương trình trọng điểm cấp quốc gia KC05/11-15 giao cho nhóm nghiên cứu của Trường Đại học Công nghiệp TP Hồ Chí Minh thực hiện. Phạm vi bài báo trình bày nội dung nghiên cứu thực nghiệm để xác định các thông số công nghệ lọc khí kết hợp làm mát kiểu ejector venturi cho mô hình dây chuyền khí hóa từ trấu để cung cấp nhiên liệu khí cho tổ hợp động cơ diesel sử dụng nhiên liệu kép và máy phát điện có công suất $5.5 \mathrm{~kW}$. Thực nghiệm đã xác định được chiều cao bố trí vòi phun nước rửa khí $\mathrm{H}=30 \mathrm{~mm}$, áp suất nước cấp vào vòi phun ở giá trị $\mathrm{P}=2 \mathrm{kgf} / \mathrm{cm}^{2}$ và lưu lượng nước cấp vào vòi phun $\mathrm{Q}=1.2$ lít/phút cho nhiệt độ làm mát và sản phẩm trấu khí hóa đạt yêu cầu về chất lượng, cung cấp cho động cơ diesel sử dụng nhiên liệu kép sử dụng chạy máy phát điện. Kết quả thực nghiệm này làm cơ sở cho việc tính toán, thiết kế, chế tạo lắp đặt cho dây chuyền khí hóa cung cấp năng lượng điện và năng lượng nhiệt cho nhà máy xay xát có năng suất bóc vỏ trấu từ 6-10 tấn/giờ cho khu vực đồng bằng sông Cửu Long.

Từ khóa. Lọc khí kiểu ướt, khí tổng hợp, đốt trấu khí hóa, thành phần khí hóa,vòi phun, áp suất nước, lưu lương nước phun, chiều cao bố trí vòi phun, nhiệt độ khí tổng hợp, tạp chất trong khí tổng hợp.

Ngày nhận bài: 28/02/2017

Ngày chấp nhận đăng: 31/05/2017 